\title{
Erratum to: Neuroprotective effect of Spirulina fusiform and amantadine in the 6-OHDA induced Parkinsonism in rats
}

\author{
I. Chattopadhyaya', Sumeet Gupta ${ }^{1 *}$, Asad Mohammed $^{2 \dagger}$, N. Mushtaq ${ }^{1 \dagger}$, S. Chauhan ${ }^{1 \dagger}$ and Saikat Ghosh ${ }^{3 \dagger}$
}

Unfortunately, the original version of this article [1] contained an error. The spelling of the author [Saikant Ghosh] name was incorrect. The spelling of the name has been corrected in the original article and is also included correctly below.

Correct version is Saikat Ghosh.

\begin{abstract}
Author details
'Department of Pharmacology, M. M. College of Pharmacy, M. M. University, Mullana, (Ambala), Haryana, India. ${ }^{2}$ College of Applied Medical Sciences, Shaqra University, Shaqra, Saudi Arabia. ${ }^{3}$ FDD-NDDS Lipid Research Group, Sun Pharma Advance Research Centre, Vadodra, Gujarat, India.
\end{abstract}

Received: 8 September 2015 Accepted: 8 September 2015

Published online: 09 September 2015

\section{Reference}

1. Chattopadhyaya I, Gupta, S, Mohammed A, Mushtaq N, Chauhan S, Ghosh S. Neuroprotective effect of Spirulina fusiform and amantadine in the 6-OHDA induced Parkinsonism in rats. BMC Complement Altern Med. 2015;15:296.

\footnotetext{
*Correspondence: sumeetgupta25@gmail.com

${ }^{\dagger}$ Equal contributors

'Department of Pharmacology, M. M. College of Pharmacy, M. M. University, Mullana, (Ambala), Haryana, India

Full list of author information is available at the end of the article

Submit your next manuscript to BioMed Central and take full advantage of:

- Convenient online submission

- Thorough peer review

- No space constraints or color figure charges

- Immediate publication on acceptance

- Inclusion in PubMed, CAS, Scopus and Google Scholar

- Research which is freely available for redistribution 